\title{
Hollywood Fatherhood: \\ Paternal Postfeminism in Contemporary Popular Cinema
}

\author{
Hannah Hamad
}

Contemporary Hollywood cinema is rife with representations of fatherhood since paternalised protagonists have become an increasingly and often overwhelmingly omnipresent feature of popular film in the early twenty-first century, while the currency of fatherhood as a defining component of ideal masculinity has emerged as a dominant cultural trope of postfeminism, and a structuring paradigm of mediated masculinity. This chapter addresses articulations of fatherhood in recent popular cinema which are discursively congruent with the sensibilities of postfeminist culture, exploring the ubiquity and centrality of fatherhood as the anchoring trope of the multiplicity of contemporary Hollywood masculinities.

The summer of 2002 marked a watershed moment for what subsequently became the pronounced and widespread paternalisation of Hollywood's cinematic output, when it saw the release of a small but significant cluster of films, all of which conspicuously pushed issues of fatherhood to the discursive fore. The films that comprised this group were Steven Spielberg's man-on-the-run science-fiction action thriller Minority Report, Sam Mendes' historical gangster melodrama Road to Perdition, and M. Night Shyamalan's moody alien invasion drama Signs. All were high grossing and wide releases, ${ }^{1}$ star vehicles, and genre films. All showcased big name directors, and all featured narratives in which the goal of the protagonist was causally and hyperbolically linked to his fatherhood. Minority Report starred Tom Cruise as John Anderton, a guilt ridden traumatized father, struggling to solve the mystery of his son's disappearance; Road to Perdition saw Tom Hanks playing against type as widowed single father Mike Sullivan, a small town mobster hit man determined to protect his son from his Chicago enemies after the boy witnesses a murder; and Mel Gibson starred in Signs as lapsed clergyman Graham Hess, a widowed single father protecting his children from malevolent and hostile extra-terrestrials. This presciently foreshadowed Spielberg's later War of the Worlds (2005), which enacted the same scenario, again from the viewpoint of a lone father, played by Tom Cruise. ${ }^{2}$ Thus, in three high profile, star led summer releases, using stock genre scenarios and conventional narratives, fatherhood predominates as a structuring thematic, narrative hook, and privileged identity formation for each protagonist, 
setting the terms and the tone for the dominant means by which Hollywood film has conceptualised postfeminist masculinities in the 2000s and beyond.

These films were indicative of an emergent representational discourse that became endemic to Hollywood storytelling, ubiquitous across the genre and budget spectrum of its output, and which has prompted a near wholesale paternalisation of Hollywood's leading men and the stories that are told through their onscreen subjectivities. The thematic prominence of fatherhood in these films, far from being bounded by the texts, instead extends to the realm of the paratextual, and beyond. Rather than a purely textual phenomenon, it instead permeates wider social and cultural discourse, colouring these films' marketing, critical reception, and the popular commentary that circulated around their releases. This is commensurate with what Amanda Ann Klein, in her foundational treatise on the topic, outlines as the pattern of events that prompts the emergence of film cycles, which she argues takes place as part of specific historically located social and cultural discourses. ${ }^{3}$

In this way, for example, promotional stills and poster campaigns that presold films like War of the Worlds, The Pursuit of Happyness (2006), Martian Child (2007), Taken (2008), The Hangover (2008), The Road (2009), Due Date (2010), Somewhere (2010), and What To Expect When You're Expecting (2012) to name only some, accentuated the paternal angles of these films, foregrounding fatherhood as a theme and prominent selling point, and anchoring their marketing, as postfeminist fatherhood has risen to discursive prominence for leading man masculinities in popular film culture to a near totalising extent. In each case, widely mediated images heavily used in the films' campaigns signified the postfeminist fatherhood of their protagonists through their designs, and via the paternally charged (often tactile) affective displays on show. The promotional poster for The Pursuit of Happyness, to take one emblematic example, is noteworthy in this regard. It depicts a besuited father, played by Will Smith, who is the only billed star on the poster, looking down and smiling upon his young son, with whom he is holding hands, and who reciprocates affection by leaning on his father's arm, head first. The boy is played by Smith's real life son Jaden, which of course was a massive boon to this marketing campaign's centralisation of postfeminist fatherhood as spectacle. ${ }^{4}$ This was consistent with the thematic and narratological centrality of fatherhood in the film itself, which, adapted from the memoir of the same name by Chris Gardner, ${ }^{5}$ narrates the American Dream from the perspective of a lone father. When his wife (Thandie Newton) leaves, Chris takes up the mantle of single fatherhood while struggling to make a living as a salesman. His dedication as a father is unwavering, as he determinedly sees his son through a period of homelessness before realising his professional potential as a stockbroker. The prominence of the paternal thematic is further compounded in the poster by its white background, which conveys no other imagery except a bright light shining behind their clasped hands, and forces fatherhood as spectacle to the top of the hierarchy of discourses at work here. Widely mediated depictions of fatherhood on the promotional 
posters for Road to Perdition and The Road are also notable, for their strikingly similar imagery. Both depict a hand in hand father and son, walking together through driving rain, and framed at identically canted angles. Viewed alongside one another, these posters are almost duplicates of one another. This suggests to me that the tried and tested currency of selling movies with postfeminist fatherhood was such that by the 2009 release of The Road it was possible to conceive a marketing campaign centred upon lone fatherhood and make judicious intertextual references to spearheading earlier campaigns, like that of Road to Perdition, via imagery, framing, and composition.

This, I would argue, corresponds with a broader discursive turn towards fatherhood as ideal masculinity in postfeminist culture. The contemporary Hollywood fatherhood film is a production cycle and cultural trend that can thus be usefully understood in relation to the postfeminist context from which it emerged. It articulates a gender discourse of postfeminist fatherhood, which is ideologically disingenuous with regard to its relationship to feminism. At the same time as appropriating a role traditionally occupied by women, through a surface discourse of involved and sensitive male parenting called for by feminists, ${ }^{6}$ postfeminist fatherhood films also shore up traditionally gender bifurcated hierarchies of agency, subjectivity, and power through a common sense veneer of postfeminist cultural logic which makes fatherhood not only culturally negotiable, but also an attractive and desirable conceptualisation of masculinity. In this way, contemporary Hollywood fathers are enabled to have their postfeminist cake, and eat it too, as fatherhood narratives allow for the privileging of masculine subjectivities, and the concomitant elision of motherhood, to be renormalised. Frequently this takes place in the absence of the cultural double standards germane to postfeminist femininities, as the cultural currency of 'having-it-all' (now an anachronism of postfeminist femininity - because postfeminist culture has long averred that women cannot) ${ }^{7}$ has found renewed license, as cultural formations like the Hollywood fatherhood film render it ever more apposite and applicable to postfeminist masculinities.

In thus conceptualising postfeminist fatherhood, I take as my starting point Angela McRobbie's now canonical thesis statement, that

post-feminism positively draws on and invokes feminism as that which can be taken into account, to suggest that equality is achieved, in order to install a whole repertoire of new meanings which emphasise that it is no longer needed, it is a spent force. ${ }^{8}$

From there I turn to Yvonne Tasker and Diane Negra's assertion that "postfeminist culture works in part to incorporate, assume, or naturalize aspects of feminism," 9 thereby appearing, disingenuously, to negate the imperative for feminist critique. I hence adopt the mandate of 
these authors to interrogate postfeminist culture and the Hollywood fatherhood film from a feminist political purview.

Writing in 2007, Tasker and Negra gestured towards the critical need in feminist film and media studies to "undertake the work of beginning to theorize postfeminist masculinity."10 Attempts have been made to conceptualise postfeminist masculinities in popular film and media culture, and these have tended to differently align them with one or the other side of a binary of reconstructed/unreconstructed masculinity, or indeed gestured towards the extent to which they attempt, coherently or otherwise, to occupy both subjectivities in an ostensible double bind of postfeminist masculinity." But even since the publication of these foundational works, scholars of postfeminist culture have continued to note the relative dearth of feminist film and media studies critiques and treatments of postfeminist masculinities, ${ }^{12}$ especially relative to the now sizeable and increasingly rich body of work on postfeminist femininities in popular film and television cultures.13 This article therefore aims to contribute to the ongoing project to conceptualise postfeminist masculinities in popular film and media, and interrogate what is at stake politically for feminism in culturally conceiving of and viewing contemporary masculinities through the lens of postfeminist fatherhood.

\section{Changing Masculinities and Fatherhood after Second-Wave Feminism}

Second wave feminism was instrumental in prompting social and cultural re-evaluations of separate spheres parenting, and the role of fathers in the lives of their children. The feminist inspired cultural re-imaginings of masculinity that followed would be the starting point for a series of discursive shifts over time, which manifested culturally in various ways, including via the representational discourse of Hollywood cinema. These have led to the naturalisation of involved fatherhood as the paradigmatic template for ideal masculinity in postfeminist popular film culture, and it has taken place through paternally inflected negotiations of all manner of variations and iterations of cinematic postfeminist masculinities.

An early indicator of the discursive traction of these feminist calls for revised and more equitable approaches to the labour share (practical and affective) of parenting, and a formative example of cultural responses to their currency and resonance, came with the initial publication in 1974 of Warren Farrell's The Liberated Man. This was a de facto mission statement for what, in the context of the time, was understood to be a polemical call-toarms for the adoption by men of a feminist masculinity. A major part of this, according to Farrell's treatise, required a re-conceptualisation of fatherhood that accorded with the aims of feminism, where parenting roles were concerned. In this way, his imperatives for fathers to be more actively and equally involved in the daily practicalities of child rearing, ${ }^{14}$ and to eschew approaches to fatherhood characterised by aloof, distant authoritarianism by, for example, being more emotionally demonstrative with their children, 15 corresponded with 
some feminist rhetoric then circulating that championed progressive gender egalitarian parenting.

However, in light of Farrell's backtracking complicity in the "backlash"16 against feminism by trumpeting the cause of beleaguered masculinity, ${ }^{17}$ the feminist credentials of his foundational take on masculinity after second-wave feminism seem shaky in retrospect. Articulations of "redefined"18 fatherhood, of the kind expounded by Farrell and his contemporaries, have since been reified in postfeminist popular film culture. This has taken place in a manner frequently at odds with the persistently gender bifurcated social realities of parenting in postfeminism, 19 and one that is evasive and circuitous with regard to the feminist politics of fatherhood. This being the case,from a contemporary standpoint, his imagined re-conceptualisation of fatherhood is better understood as proto-postfeminist.

Farrell's proposed model of redefined fatherhood was hence a significant cultural precursor to some of the ideologically disingenuous and highly financially successful cinematic articulations of fatherhood that followed second wave feminism in the late 1970s and early 1980s. These include films such as Kramer Vs. Kramer (1979) in which an inept lone father transforms his parenting and his relationship with his son when the mother leaves, 20 and Mr Mom (1983) in which gendered parenting roles are comically inverted to effect the transformation of the father from inept mother substitute, to paragon of ideal masculinity. ${ }^{21}$. These canonical examples would themselves become the cultural touchstones and ur-texts, both for the cycle of fatherhood films that followed in the late 1980s and early 1990s,22 and thereafter for contemporary Hollywood's narratives of postfeminist fatherhood.

\section{Emergent Discourses of Postfeminist Fatherhood in 1980s and 1990s Hollywood}

In popular cinema these discourses of changing masculinities were most prominently mediated through a much discussed cycle of family comedies centred upon the pitfalls of male parenting in a domestic environment with recently rethought mores regarding domestic division of labour and the gender specificity of parenting roles. The most well known entries in this cycle were the aforementioned Mr Mom (1983); Three Men and a Baby (1987) in which the deficient masculinities of the eponymous protagonists are recuperated through their haphazard parenting of an unexpectedly acquired baby girl, and which Modleski canonically read as popular culture's foundational tract on paternal postfeminist masculinity,23 as well subsequently as Parenthood (1989), Look Who's Talking (1989), Kindergarten Cop (1990) and Junior (1994). Often overlooked - and not without reason as they were not the runaway box office successes that some films from this cycle were ${ }^{24}$ some lesser known and discussed examples included Paternity (1981), Ghost Dad (1990), Cop and a Half (1993) and Fathers' Day (1997), all of which followed the pattern of attempting to create humour from a narrative of inept but subsequently transformed and ameliorating fatherhood. 
In line with one of the cultural functions of comedy to appear to "challeng[e] norms, hierarchies, and established systems," 25 the aforementioned are all comedic family films. However, notwithstanding the efficacy of negotiating these shifting mores of masculinity through the safe representational space of the family comedy, a larger cultural conversation was taking place at this time about sensitive masculinity, meaning that the discursive terrain occupied by this gender discourse was broader than this symptomatic film cycle, and its various cultural permutations have been interrogated manifold by scholars. 26 Another notable 1990s example, from the purview of genre, was the turn towards the paternal in the action film, seen over the course of the decade, as fatherhood coloured the characterisation of central characters and narratives of, for example, Terminator 2: Judgement Day (1991), True Lies (1994), Independence Day (1996), Ransom (1996) Air Force One (1997), Con Air (1997), Dante's Peak (1997), Face/Off (1997), Jurassic Park: The Lost World (1997), Volcano (1997), Armageddon (1998), Lethal Weapon 4 (1998), Lost In Space (1998), and Mercury Rising (1998). As has been argued by numerous scholars, the 1990s paternalisation of these action films at once enabled the reification of patriarchal family values alongside an apparent accommodation of changing mores regarding ideal masculinity. ${ }^{27}$ This took place through their paternally signified, and therefore 'sensitive' leading men, thus offsetting what would otherwise be the problem of negotiating the troublingly recidivist masculinities on show. The 1990s were thus key years in the formation of emergent discourses of postfeminist fatherhood in Hollywood, giving rise to a plethora of such representations. Further, the decade was also significant for the spike in scholarship on mediated masculinities.

\section{Postfeminist Fatherhood and Contemporary Hollywood}

Just as scholars have argued the case for a discursive shift in popular cinematic masculinities in the nineties towards qualities like sensitivity and emotionalism, I argue that the emergent discourses of postfeminist masculinity in popular cinema at that time were solidified, normalised and naturalised by the early 2000s. The ensuing decade gave rise to a more confidently articulated multiplicity of postfeminist masculinities across the genre and budget spectrum of Hollywood's output, which were anchored by the structuring masculine identity paradigm of fatherhood, and its omnipresence across an abundance of narratives of paternity. Hollywood fatherhood in the twenty-first century thus cannily navigates the mores of its postfeminist and socio-cultural context, thereby negotiating its status as the new hegemonic masculinity. ${ }^{28}$

Chiming with the symptomatic ubiquity of representations of fatherhood in Hollywood, the last few years have correspondingly witnessed the emergence of a glut of new scholarly literature on the gender politics, sociology, psychology and practice of contemporary fatherhood, which attempts, in different ways, to account for its discursive 
prominence and socio-cultural visibility in this historical moment. ${ }^{29}$ Meanwhile, the cultural trend of articulating postfeminist masculinities in paternal terms has also noticeably permeated the realms of mediated public sphere commentary and debate. This has given rise to a new popular cultural lexicon of paternally inflected sound bites and buzz phrases, some of which are notable re-appropriations of maternally inflected equivalents circulating (if not already debunked) in postfeminist culture. Here, the move in postfeminism towards enabling men's parental leave is "The Daddy Track."30 Downshifting fathers who forego workplace advancement and economically driven external signifiers of success and wealth are said to evince the "new daditude." 31 The effortlessly multitasking and breadwinning domestic hero double-shifters, simultaneously navigating the public and private spheres to equally admirable levels of unflappable efficiency, are succinctly and repeatedly referred to as "superdad." 32 And a rhetoric circulates that speaks directly to the extent to which postfeminist fatherhood is being positioned as desirable to women through its framing as "hot" and "sexy." 33 Terms and epithets like these are commonplace in popular discourse surrounding fatherhood and are indicative of the ease and comfort with which postfeminist culture now aligns its conceptualisations of ideal masculinity with fatherhood, as Hollywood cinema has multifariously done over the last decade.

Writing in the mid-2000s on Hollywood's changing takes on fatherhood since the postwar 1940s, Stella Bruzzi acknowledged the "variety as well as quantity" of films that centralised fatherhood in the current and preceding decade,34 citing as examples mainstream movies like Big Daddy (1999), The Family Man (2000) and About a Boy (2003), all of which recuperate the deficient masculinities of their protagonists through fatherhood. Since then, Yvonne Tasker has pointed to "male parenting as a prominent feature of postfeminist media culture", 35 and contemporary Hollywood films like Daddy Day Care (2003), which qualifies the postfeminist masculinity of Charlie Hinton's (Eddie Murphy) stay-athome fatherhood by entrepreneurialising it in the form of a father run day care centre, and Cheaper By The Dozen (2003), in which Steve Martin is hyper-paternalised as father of twelve, Tom Baker. Nicola Rehling has similarly observed the popular cinematic "trend of representing straight white masculinity as paternity," and hence "Hollywood's current fascination with fatherhood,"36 which she exemplifies with reference to films like Finding Nemo (2003), a narrative of protectorate fatherhood from the perspective of a widowed single father, and The Incredibles (2004), which revalidates the emasculated fatherhood of Bob Parr (Craig T. Nelson) by aligning it with super-heroism.

Correspondingly, a central contention of this article is that in the early twenty-first century, Hollywood has produced a proliferation of distinctly identifiable cycles and subcycles of films that discursively prioritise fatherhood in the representation, narrative, characterisation, marketing and promotional activities of the films that comprise them, and the view from 2012 suggests that these cycles are not yet spent, as new iterations of the 
postfeminist fatherhood film continue to emerge that both perpetuate extant discourses of fatherhood and develop the cycle such that it continues to remain culturally viable.

Cycles and Sub-Cycles of Postfeminist Fatherhood Films in Contemporary Hollywood Cinema The emergent field of 'cycle studies' offers a useful approach to understanding and attempting to account for the abundance of narratives of postfeminist fatherhood in recent popular cinema. This is due to the emphasis it places on the relationship between contextual factors, the emergence and popularity of film cycles, and the cultural and social discourses circulating around and through them. In this way, it is a productive entry point into exploring the relationship between postfeminist culture and the contemporary Hollywood fatherhood film.

As Steve Neale states, "the terms 'trend' and 'production trend' have in recent years figured prominently as alternatives or additions to 'genre' as means by which to chart the different strands in Hollywood's output," 37 and he cites Tino Balio as a noteworthy early spearhead for discussing groupings of films in this way. ${ }^{38}$ Latterly, this approach to studying Hollywood production trends has been significantly developed by Amanda Ann Klein, in her foundational work conceptualising the film cycle, mapping the terrain of American film cycles over time, and explicating the relationship between cycle studies, and genre studies. ${ }^{39}$ As Klein states:

the formation and longevity of film cycles are a direct result of their immediate financial viability as well as the public discourses circulating around them, including film reviews, director interviews, studio-issued press kits, movie posters, theatrical trailers, and media coverage... A film cycle will form only if its originary film - the film that establishes the images, plot formulas, and themes for the entire cycle - is financially or critically successful. That is, the originary film must either draw a large audience or become a subject of discussion in the media. The buzz (financial or critical) surrounding the originary film convinces other filmmakers to make films that replicate the successful elements of that film, thus forming a cycle. 40

As indicated at the outset, I understand the contemporary Hollywood fatherhood film as having originated from a financially successful cluster of big-budget, saturation release, auteur helmed, A-list star vehicle, summer tent-pole movies; although discursively linked to the aforementioned cycles that preceded it. In line with Klein's thesis on how film cycles emerge, the 2002 clustered release, box-office success, and cultural resonance of Minority Report, Signs and Road to Perdition caused the proliferation of films about fathers and fatherhood to become a media talking point.

In July of that year, upon the US release of Road to Perdition, the New York Times movie critic A.O. Scott discussed a then current group of films he identified as thematically centralising "onscreen paternity," also citing Gladiator (2000), The Patriot (2000), In The Bedroom (2001), and Minority Report as entries. ${ }^{41}$ He discussed their "deep similarities of 
theme and symbolism" noting the use of the most bankable male stars to portray these screen fathers, naming Russell Crowe, Mel Gibson, Tom Cruise and Tom Hanks. He remarks upon the extent to which they appear to be playing "against type." However, with hindsight, we can understand these films as contributing factors in what would become a full-on paradigm shift in Hollywood's articulation of ideal masculinity via its roster of male stars. This saw the wholesale paternalisation first of the images of this group of stars, and subsequently a seeming multitude of male stars and celebrities at all levels of marquee value and bankability. This extended beyond Hollywood, and cut across the spectrum of noughties media culture, as I have elsewhere demonstrated to be the case. .42

Then, in August 2002, again in response to the plethora of cinematic articulations of fatherhood that were then emerging out of Hollywood, 'Fathers in Film' was the topic of an hour-long roundtable discussion on Chicago Public Radio's current affairs talk show 'Odyssey.' Host Gretchen Helfrich introduced the show with the following explanatory set-up, singling out the clustered release of this trio of films as the impetus for the debate:

A cop haunted by his son's murder; a hitman struggling to protect his family from violence; a lapsed priest trying to save his children from aliens - these are just some of the challenges facing movie dads this summer, as Hollywood brings us extreme parenting. 43

Each of the films that comprised this cluster of star led genre narratives is itself indicative of at least one thematically congruent, genre specific, or trope oriented sub-cycle within the umbrella cycle of narratives of postfeminist fatherhood, as well as symptomatic of a turn towards embodied fatherhood in the screen oeuvre of each star. ${ }^{44}$

For example, Signs and Minority Report both prefigured the ensuing cycle of paternalised narratives of social disintegration and apocalypse, such as War of the Worlds, I Am Legend (2007), The Happening (2008), The Road (2009), 2012 (2009), Knowing (2009) and Skyline (2010), all of which centralise protectorate fatherhood in narratives that place fathers and their children in extreme and exceptional circumstances that test the limits of their paternal credentials. Writing in the mid 2000s, Kirsten Moana Thompson argued that such narratives of apocalypse provide an apt device for popular cinema to "return to an idealized fantasy of family values", 45 enabling a circumvention if not an outright repudiation of some of the more pluralistic ways in which understandings and different formations of the family can be conceived in postfeminism, as well as facilitating the recuperation of hitherto outmoded conceptualisations of masculinity and fatherhood. This sub-cycle thus effectively renegotiates a return to more traditional notions of this epitomic identity paradigm of masculinity centred upon uncompromising protectiveness. ${ }^{46}$ Ideologically related to this cycle is another, which the success and cultural resonance of Signs also prefigured, and this is a cycle of paternalised homes-under-siege films, ${ }^{47}$ which also includes Cold Creek Manor (2003), Hostage (2005), Firewall (2006) and Law Abiding Citizen (2009), and which emerged 
congruent with a masculinist post-9/11 cultural logic of protecting the family homestead.48 Road to Perdition can also be counted amongst the glut of Hollywood historical epics that James Russell argues constituted a prominent film cycle and resurgence of the genre in the 1990s and early 2000s.49 I would further argue that it came as part of a distinctly paternally themed sub-cycle augured by Gladiator, and that subsequently included The Patriot, Troy (2004), Cinderella Man (2005), Apocalypto (2006) and Valkyrie (2008), and which through their period settings exemplify the tendency in postfeminism to locate and idealise masculinities in and of the past. This sub-cycle thus locates latter day postfeminist fatherhood in both colonial and depression era America, ancient Greece, Mesoamerica in the time of the conquistadors, and even Nazi Germany, going so far as to paternalise the well worn World War II narrative of the 'good Nazi,' as the goodness of Klaus von Stauffenberg (Tom Cruise) is signified by his tactile affective displays towards his children. Road to Perdition was also a significant early entry in what would become a cycle of male melodramas and tragicomedies of (frequently widowed) single fatherhood. 50 This has so far included Finding Neverland (2004), Jersey Girl (2004), The Pursuit of Happyness (2006), Dan In Real Life (2007), Grace Is Gone (2007), Martian Child (2008), World's Greatest Dad (2009), The Boys Are Back (2009), The Descendants (2011), and We Bought a Zoo (2011), and stands as a striking example of one of many postfeminist appropriations of traditionally feminine cultural forms, in service to the efficacy and negotiability of postfeminism's latter day recentralisation of masculine subjectivities, as lone father protagonists go on emotional journeys through their respective narratives, culminating in strengthened bonds with their children.

Postfeminist Fatherhood in Hollywood Today: The View From 2012

According to Klein's rationale "most film cycles are financially viable for only five to ten years. After that point, a cycle must be updated or altered in order to continue to turn a profit." 51 Ten years on from the release of the group of films I proposed at the outset to be the "originary" 52 cluster that kick-started the widespread normalisation of postfeminist fatherhood as ideal masculinity in contemporary Hollywood, the economic and cultural viability of the cycle shows little sign of waning.

For example, at the time of writing, the number one film at the UK box office is the British produced The Woman In Black (2012).53 The film, a period supernatural thriller starring Daniel Radcliffe as a widowed single father, haunted by the malevolent spirit of an aggrieved mother, is an adaptation of a Susan Hill novel, which has markedly foregrounded and heavily accentuated the fatherhood of the protagonist, relative to the understatedly paternally inflected narrative of the literary source material, ${ }^{54}$ and adhering to the cultural imperative for ideal masculinity in contemporary popular cinema to be articulated in paternal terms. This is indicative not only of the fact that this phenomenon of mediated masculinity is not limited to the output only of Hollywood, but also of the fact that the 
postfeminist fatherhood film is another manifestation of the "discursive harmony" 55 between Anglo and American postfeminisms, and hence the congruity between the construction and articulation of postfeminist fatherhood in British films such as this, and comparable American produced fare.

Further, at the tail end of 2011, Melena Ryzik, writing in the New York Times, noted that "there's a preponderance of struggling (but hot) single fathers" 56 in her round-up of the year in American independent cinema, citing the desirability of the single fatherhood enacted by George Clooney in The Descendants, Brad Pitt in Moneyball (2011) and Matt Damon in We Bought a Zoo. Similarly, Sasha Stone, writing for Awards Daily, cited the same three films, noting that amongst the year's crop of Oscar hopefuls, there were a slew of "single fathers" and "vanishing mothers," as if this had not been the state of play across the spectrum of Hollywood's less Oscar-worthy output for the duration of the preceding decade. She proceeds to valorise what she evidently reads as their paternalised ideal masculinities:

One of the threads running through this year's Oscar race is the single father who must pull things together for the sake of his kids... Stories about single dads are all the rage this year partly because films don't really get made without a strong male star driving them ... Meanwhile, I'm into these men, these single dads who cry, these superheroes who want to save the world and make it a better place. All three of them do in their own way. ${ }^{57}$

Thus, ten years on from the summer of 2002, and the cluster of films that most visibly kickstarted Hollywood's turn towards the paternal, the longevity of the cycle is manifest, and the fatherhood film shows no signs of losing ground in terms of cultural viability. If anything it is gaining ground in terms of cultural capital, as it has crossed over first from the realm of the comedic, then into the broader mainstream where a cross section of Hollywood's output reveals its representational recurrence throughout, and now into the realms of middlebrow, independent and art-house cinemas. Epitomic of this development is the paternal thematic at the heart of Terrence Malick's much discussed, as maligned as it was lauded, metaphysical treatise on fatherhood, The Tree of Life (2011). So, the postfeminist fatherhood film, notwithstanding the 'quality' credentials of a forerunner example like Road to Perdition, is therefore now acquiring a hitherto denied level of cultural legitimacy, due ostensibly to its conspicuous incursion into the realms of the middlebrow, the chord it is apparently striking with audiences of crossover art-house films like The Descendants, and the discourse of 'quality' that accompanies any discussion of films identified as Oscar-worthy. This, as indicated above, has prompted critics and popular commentators to sit up and take notice of this representational recurrence in screen masculinities, a decade on from, not even its inception, but its top-down pervasion of high-end Hollywood cinema.

Meanwhile in Hollywood, the multi-ethnic spectacle of postfeminist fatherhood on display in What To Expect When You're Expecting appears to offer a superficial challenge to 
the discursive dominance of whiteness in narratives of postfeminist fatherhood, the status quo of which is further evidenced by the ghettoisation of African American and Latino fatherhood within the realm of the family comedy. This can be seen in films like Daddy Day Care, Johnson Family Vacation (2004), My Baby's Daddy (2004), Are We There Yet? (2005) and Little Man (2006). Or in Will Smith films like The Pursuit of Happyness and I Am Legend, which are shrouded in disingenuously colourblind discourses of the post-racial. What to Expect When You're Expecting is inspired by a self-help manual of the same name, intended for expectant mothers. ${ }^{58}$ Yet even in this seemingly unlikely case, the film and the ancillary materials circulating around it manage to shift the discursive emphasis considerably towards fatherhood and masculinity, which can be seen in one of the film's most widely mediated promotional images. The movie poster in question depicts a line of fathers purposefully pushing strollers down the street together, in a culturally apposite discursive intersection of homosociality and postfeminist fatherhood, manifest in the tagline "There is no judging in 'Dudes Group'". The cultural logic and political efficacy of popular cinematic postfeminist fatherhood as a means by which to at once "account" for feminism and reify new hegemonic masculinities, therefore remains steadfast. 59

Having said this, it is possible to identify seeds of backlash being sown at the margins of the mainstream as films like There Will Be Blood (2007), The Wrestler (2008), and Crazy Heart (2009) staunchly resisted the possibility of redemption for their flawed and self-destructive paternally signified protagonists; while the knowing hyperbole of the anti-super-heroism of Nicolas Cage's 'Big Daddy' in Kick-Ass (2010) could augur a turn towards irony in treatments of postfeminist fatherhood, bearing out Klein's contention that before backlash against a film cycle, there sometimes comes parody. ${ }^{60}$ Nonetheless, this, and whether the (ultimately misplaced) Oscar-buzz that surrounded 2011 's postfeminist fathers will be the last Hollywood hurrah for postfeminist fatherhood as ideal masculinity remains to be seen.

1 Minority Report opened in 3001 theatres, and grossed \$358,372,926 worldwide; Road to Perdition opened in 1797 theatres, and grossed \$181,001,478 worldwide; and Signs opened in 3264 theatres, and grossed $\$ 408,247,917$, making it the most financially successful film of this cluster, www.boxofficemojo.com.

2 Hannah Hamad, 'Extreme Parenting: Recuperating Fatherhood in Steven Spielberg's War of the Worlds (2005)', in Feminism at the Movies: Understanding Gender in Contemporary Popular Cinema, eds. Hilary Radner and Rebecca Stringer, pp.241-253.

3 Amanda Ann Klein, American Film Cycles: Reframing Genres, Screening Social Problems and Defining Subcultures (Austin: University of Texas Press, 2011), p.9.

$4 \quad$ Publicity for this film frequently zoned in on the onscreen/offscreen father and son pairing of Will and Jaden Smith. One prominent example was Entertainment Weekly's December 2006 lead story, featuring a cover portrait of a beaming Jaden Smith with his arms flung around the next of his beaming father. Neil Drumming, 'Will Smith's Pursuit of 
'Happyness' May Lead to Oscar' Entertainment Weekly 911 (2006),

http://www.ew.com/ew/inside/issue/0,,ewTax:911,00.html.

${ }^{5}$ Chris Gardner, The Pursuit of Happyness (New York: Amistad/HarperCollins, 2006).

6 As Kimmel rhetorically states, 'Who, after all, has been asking... men to take a larger part in child care and housework all these decades?' Michael Kimmel, Manhood In America: A Cultural History (New York: The Free Press, 1996), p.303.

7 See, for example, the retreatist paradigm theorised by Diane Negra in relation to downshifting cultural narratives of postfeminist femininity in What a Girl Wants?: Fantasizing the Reclamation of Self in Postfeminism (London and New York: Routledge, 2009), pp.15-33; and Joanne Hollows, 'Can I Go Home Yet? Feminism, Post-Feminism and Domesticity' in Feminism and Popular Culture, eds. Joanne Hollows and Rachel Moseley. (Oxford and New York: Berg, 2006), pp.97-1 18.

8 Angela McRobbie, 'Post-Feminism and Popular Culture' Feminist Media Studies 4:3 (2004), 255.

9 Yvonne Tasker and Diane Negra, 'Introduction: Feminist Politics and Postfeminist Culture', in Interrogating Postfeminism: Gender and the Politics of Popular Culture (Durham and London: Duke University Press, 2007), 2.

10 Tasker and Negra, 'Introduction,' 14.

11 For these kinds of foundational treatises on mediated postfeminist masculinities see for example, Sarah Projansky, Watching Rape: Film and Television in Postfeminist Culture (New York: New York University Press, 2001), pp.84-86; Yvonne Tasker, 'The Family In Action', in Action and Adventure Cinema, ed. Yvonne Tasker. (London: Routledge, 2004), pp.252-266; Estella Tincknell, Mediating the Family: Gender, Culture and Representation (London: Hodder Arnold, 2005), pp.55-76; Bonnie J. Dow, 'The Traffic in Men and the Fatal Attraction of Postfeminist Masculinity' Women's Studies in Communication. 29: 1 (2006), pp.113-131; Benjamin A. Brabon, 'The Spectral Phallus: Re-Membering the Postfeminist Man', in Postfeminist Gothic: Critical Interventions in Contemporary Culture, eds. Benjamin A. Brabon and Stéphanie Genz. (Basingstoke and New York: Palgrave Macmillan, 2007), pp.56-67; Stéphanie Genz and Benjamin A. Brabon, Postfeminism: Cultural Texts and Theories (Edinburgh: Edinburgh University Press, 2009), pp.132-144.

12 See, for example: Dow, 'The Traffic In Men', p.116; Karen Boyle, 'Feminism Without Men: Feminist Media Studies in a Post-Feminist Age' in Feminist Television Criticism, $2^{\text {nd }}$ edition, eds. Charlotte Brunsdon and Lynn Spigel (Maidenhead: McGraw Hill Education/Open University Press, 2007), p.183; Elana Levine, 'Feminist Media Studies in a Postfeminist Age' Cinema Journal, 46: 4 (2009), p.143.

13 See, for example: Stéphanie Genz, Postfemininities in Popular Culture (Basingstoke and New York: Palgrave Macmillan, 2009); Negra, What a Girl Wants?; Susan J. Douglas, The 
Rise of Englightened Sexism: How Pop Culture Took Us From Girl Power to Girls Gone Wild (New York: St Martin's Press, 2010); Rosalind Gill and Christina Scharff eds, New Femininities: Postfeminism, Neoliberalism and Subjectivity (Basingstoke and New York: Palgrave Macmillan, 2011); Anthea Taylor, Single Women in Popular Culture: The Limits of Postfeminism (Basingstoke and New York: Palgrave Macmillan, 2012).

14 Warren Farrell, [1975] The Liberated Man (New York: Berkley Books, 1993), p.1 19.

15 Ibid., p.118.

16 Susan Faludi, Backlash: The Undeclared War Against Women (London: Chatto \& Windus, 1991).

17 The recidivist back-pedalling and lamentation of male victimhood in Farrell's published work on masculinities begins contemporaneous with the emergence of the more recuperative factions of the men's movement in the early 1990s, and continues on into latter day postfeminism. See for example, Warren Farrell, The Myth of Male Power (New York: Simon \& Schuster, 1993); and Warren Farrell, Steven Svoboda and James P. Sterba, Does Feminism Discriminate Against Men?: A Debate (Oxford and New York: Oxford University Press, 2008).

18 Farrell, The Liberated Man, p.118.

19 UK and US studies have shown that the majority of childcare is still undertaken by women. See for example, Lucy Ward, 'Babies and Jobs: No Easy Choices,' Guardian (25 November 2009), p.9; and Jason Fields, America's Families and Living Arrangments: 2003, Current Population Reports P20-553 (Washington DC: US Census Bureau).

20 Kramer Vs. Kramer was the highest grossing film of 1979. See: 'Most Popular Feature Films in 1979', IMDB, Accessed: 13 April 2012, http://www.imdb.com/year/1979/.

$21 \quad$ Mr Mom was the ninth highest grossing film of 1983. See: '1983 Domestic Grosses', Box Office Mojo, Accessed: 13 April 2012, http://www.boxofficemojo.com/yearly/chart/? yr= $1983 \& \mathrm{p}=. \mathrm{htm}$.

22 Regarding the cultural influence of the paradigm of masculinity propounded in $\mathrm{Mr}$ Mom, see: Mary Douglas Vavrus, 'Domesticating Patriarchy: Hegemonic Masculinity and Television's "Mr Mom"' Critical Studies in Media Communication, 19: 3 (2002), pp.352-275. On the significance of Kramer Vs. Kramer as a social document of changing mores surrounding the gendered labour share of parenting, see: Stella Bruzzi, Bringing Up Daddy: Fatherhood and Masculinity in Post-War Hollywood (London: BFI, 2005), pp.107-1 14.

23 Tania Modleski, Feminism Without Women: Culture and Criticism in a 'Postfeminist' Age (New York and London: Routledge, 1991), pp.76-89.

$24 \quad$ Three Men and a Baby was the highest grossing film of 1987; Look Who's Talking and Parenthood were among the top ten highest grossing films of 1989 (4th and $9^{\text {th }}$ respectively); and Kindergarten Cop was the tenth highest grossing film of 1990. See: Box Office Mojo, Accessed: 13 April 2012, www.boxofficemojo.com. 
25 Modleski, Feminism Without Women, p.86. See also: Geoff King, Film Comedy (London: Wallflower, 2002), pp.129-169; Nicole Matthews, Comic Politics: Gender in Hollywood Comedy After The New Right (Manchester: Manchester University Press, 2000), pp.99-134; Tincknell, Mediating the Family, pp.68-72.

26 Ibid., pp.76-89; Elizabeth G. Traube, Dreaming Identities: Class, Gender, and Generation in 1980s Hollywood Movies (Boulder: Westview Press, 1992), pp.123-169; Susan Jeffords, 'The Big Switch: Hollywood Masculinity in the Nineties' in Film Theory Goes to the Movies, eds. Jim Collins, Hilary Radner, and Ava Preacher Collins (New York and London: Routledge, 1993), pp.196-208; Susan Jeffords, 'Can Masculinity Be Terminated?' in Screening the Male: Exploring Masculinities in Hollywood Cinema, eds. Steven Cohan and Ina Rae Hark (London and New York: Routledge, 1993), pp.245-262; Fred Pfeil, White Guys: Studies in Postmodern Domination and Difference (London and New York: Verso, 1995), pp.37-70; Jude Davis and Carol R. Smith, Gender, Ethnicity and Sexuality in Contemporary American Film (Edinburgh: Keele University Press, 1997), pp.16-25; Sarah Harwood, Family Fictions: Representations of the Family in 1980s Hollywood Cinema (Basingstoke: Macmillan, 1997), pp.73-101; Tincknell, Mediating the Family, pp.55-76; Nicola Rehling, Extra-Ordinary Men: White Heterosexual Masculinity in Contemporary Popular Cinema (Lanham: Lexington Books, 2009), pp.55-67.

27 Mark Gallagher, 'I Married Rambo: Spectacle and Melodrama in The Hollywood Action Film', in Mythologies of Violence in Postmodern Media, ed. Christopher Sharrett. (Detroit: Wayne State University Press, 1999), pp.199-225; Karen Schneider, 'With Violence If Necessary: Rearticulating the Family in the Contemporary Action-Thriller', Journal of Popular Film and Television. 27: 1 (1999), pp.2-11; Tasker, 'The Family In Action'; Philippa Gates, Detecting Men: Masculinity and the Hollywood Detective Film (Albany: State University of New York Press, 2006), pp.145-153.

28 R. W. Connell, Gender and Power: Society, the Person and Sexual Politics (Cambridge: Polity Press, 1987).

29 See, for example: Anna Gavanas, Fatherhood Politics in the United States: Masculinity, Sexuality, Race, and Marriage (Urbana and Chicago: University of Illinois Press, 2004); Lynne Segal, 'The Good Father: Reconstructing Fatherhood' in Slow Motion: Changing Masculinities, Changing Men, 3rd revised edition (Basingstoke and New York: 2007), pp.22-49; Esther Dermott, Intimate Fatherhood: A Sociological Analysis (London and New York: Routledge, 2008); Peter B. Gray and Kermyt G. Anderson, Fatherhood: Evolution and Human Paternal Behaviour (Cambridge, MA: Harvard University Press, 2010); and Tina Miller, Making Sense of Fatherhood: Gender, Caring and Work (Cambridge: Cambridge University Press, 2011). 

Steiner, 'The Daddy Track,' Washington Post (31 March 2006); Anne Jarrell, 'The Daddy Track,' Boston Globe (8 July 2007).

31 Sharon Jayson, 'Today's Guys Parent with a New Daditude,' USA Today (17 June 2008), p.1. Thanks to Diane Negra for this article.

32 David Brindle, 'Men Under Pressure to Become Superdads,' The Guardian, July 16, 1999; Sandra Tsing Loh, 'Let's Call The Whole Thing Off,' The Atlantic, July/August, 2009, 125; Roman Krznaric, 'Man About The House' The Guardian, January 14, 2012.

33 Hannah Hamad, "'Hollywood's Hot Dads!": Tabloid, Reality and Scandal Discourses of Celebrity Postfeminist Fatherhood.' Celebrity Studies, 1: 2 (2010), pp.154-157.

34 Bruzzi, Bringing Up Daddy, p.153.

35 Yvonne Tasker, 'Practically Perfect People: Postfeminism, Masculinity and Male Parenting in Contemporary Cinema' in A Family Affair: Cinema Calls Home, ed. Murray Pomerance (London: Wallflower, 2008), p.176.

36 Rehling, Extra-Ordinary Men, p.65.

37 Steve Neale, 'Introduction' in Genre and Contemporary Hollywood, ed. Steve Neale, p.4.

38 Tino Balio, Grand Design: Hollywood as a Modern Business Enterprise, 1930-1939 (New York: Scribners, 1993).

$39 \quad$ Klein, American Film Cycles.

$40 \quad$ Ibid., p.4.

41 A. O. Scott, 'Fathers and Sons and Hollywood Law', New York Times (21 July 2002).

42 Hamad, "'Hollywood's Hot Dads"', pp.151-169.

43 Gretchen Helfrich, 'Fathers in Film', Odyssey, Chicago Public Radio (9 August 2002).

44 Cruise, Gibson and Hanks had all previously played different iterations of postfeminist fatherhood in iconic formative films that pre-figured this cycle, in Jerry Maguire, Ransom and Sleepless in Seattle, respectively; and they would go on to do so subsequently in, for example, War of the Worlds, The Beaver (2011) and Extremely Loud \& Incredibly Close (2011), respectively.

45 Kirsten Moana Thompson, Apocalyptic Dread: American Film at the Turn of the Millennium (Albany: State University of New York Press, 2007), p.153.

46 For explications of this take on fatherhood in this sub-cycle, see: Joshua Gunn, 'Father Trouble: Staging Sovereignty in Spielberg's War of the Worlds', Critical Studies in Media Communication, 25: 1 (2008), pp.1-27; and Hamad, 'Extreme Parenting', pp.241-253.

47 See: James Morrison, 'Hostages and Houseguests: Class and Family in the New Screen Gothic', in A Family Affair: Cinema Calls Home, ed. Murray Pomerance (London and New York: Wallflower, 2008), pp.189-201. 
48 See: Susan Faludi, The Terror Dream: Fear and Fantasy in Post-9/11 America (New York: Metropolitan, 2007); and James Hay, 'Designing Homes to Be the First Line of Defense: Safe Households, Mobilization, and the New Mobile Privatization', Cultural Studies, 20: 4/5 (2006), pp.349-377.

49 James Russell, The Historical Epic \& Contemporary Hollywood (London and New York: Continuum, 2007).

50 The 'originary film' (to use Klein's term) that set the benchmark for the widowed single father paradigm of postfeminist masculinity was of course Sleepless In Seattle (1993), while the benchmark for the male melodrama of postfeminist fatherhood was set by films like Forrest Gump (1994) and Jerry Maguire (1996). See: Rehling, Extra-Ordinary Men, p.65; and Robert Lang, Masculine Interests: Homoerotics in Hollywood Film (New York: Columbia University Press, 2002), pp.273-302.

$51 \quad$ Klein, American Film Cycles, p.4.

52 Ibid.

53 'United Kingdom and Ireland and Malta Box Office Index', Box Office Mojo, Accessed: 6 March 2012. http://boxofficemojo.com/intl/uk/.

$54 \quad$ Susan Hill, The Woman In Black (London: Hamish Hamilton, 1983).

55 Tasker and Negra, 'Introduction', p.13.

56 Melena Ryzik, 'In Film, So Many Men on the Verge of a Crisis', New York Times (1 December 2011), p.1. Thanks to Diane Negra for this article.

57 Sasha Stone, 'Oscars 2011: Single Fathers and the Vanishing Mothers', Awards Daily (27 November 2011), Accessed: 7 April 2012, http://www.awardsdaily.com/2011/11/oscars2011 -single-fathers-and-the-vanishing-mothers/.

$58 \quad$ Heidi Murkoff and Sharon Mazel, What To Expect When You're Expecting (New York: Workman Publishing Company, 1984).

59 McRobbie, 'Postfeminism and Popular Culture', p.255.

$60 \quad$ Klein, American Film Cycles, pp.14-15 and pp.175-178. 